\title{
PRODUCTIVE PERFORMANCE OF HUBBARD CLASSIC BROILER BREEDERCHICKENS UNDER DIFFERENT HOUSING SYSTEMS
}

\author{
A.I. El-Faham; S.A. Ibrahim; S.A. El-Safty; Nematallah G.M. Ali; M.S. Hassanien and \\ G.N. Rayan
}

Poult. Prod. Dept. Fac. of Agr., Ain Shams Univ. Egypt.

\section{SUMMARY}

$\mathrm{T}$ his investigation aimed to evaluate the effect of two housing types (closed and semi-closed), broiler breeder age and their interaction on broiler breeder performance during egg production (2545 wks ofage), at a private local broiler breeder farm in Alexandria desert road. The results indicated that: Housing system significantly affected on body weight which was heavier in semi-closed compared to closed housing system. No significant difference in egg production, egg weight and feed consumption during egg production period of breeder under two housing system. Housing system significantly affected on mortality rate percentage of breeder during egg production period which was higher under closed housing type. Body weight, egg production, egg weight, feed consumption and mortality rate of female broiler breeders were significantly affected by breeder age. Generally, in most cases, the interaction between type of house and age of breeder hens for studied criteria were insignificant.

Keywords: Housing type, Age, Breeders and egg production period

\section{INTRODUCTION}

The consumption of poultry meat has increased worldwide over the past 50 years, primarily because it has become more competitively priced and more available than other meat sources. Moreover, in Egypt there has been a rapid increase in the number of companies owning broiler parent and grandparent stocks leading to an increase in the population of meat type chicken Kosbaet al. (2015). In addition, for improving and maximizing the potentiality of production and reproduction of breeder flocks, manipulating the nutritional, physiological and environmental factors are necessary (Hassanien, 2015).

Gomes De Oliveria and JaséCamargos Lara (2016) showed that, the environment during production plays a fundamental role in modern poultry farming. Temperature, humidity, air velocity and radiation are the factors that mainly affect poultry and can compromise homeothermy.

Bell and Weaver (2001) reported that housing and management of poultry parent stock is mainly aimed at providing the conditions that ensure optimum performance of the birds. Recently, the closed housing system provides the optimum circumstances (temperature, ventilation, artificial lighting, cleaning and disinfection facilities) for the birds, it is managed more scientifically than the open one. Moreover, the economic study showed the superiority of closed systems economic efficiency characters than the semi-closed (Ashoraet al., 2016). On the other hand, Rayan et al. (2015) reported that the productive performance of the broiler breeders during growth and egg production stages was better in semi-closed houses compared with traditional open houses.

However, there were not enough information about the relationship between different housing types and broiler breeder performance. Therefore, the present study was conducted to evaluate the effect of housing type semi-closed and closed system, broiler breeder age and their interaction in productive performance of Hubbard classic broiler breeder hens.

\section{MATERIALS AND METHODS}

This study was carried out on Hubbard classic broiler breeder's strain during egg production period (25-45 wks) of age at a private local broiler breeder farm in Alexandria desert road under the two housing types (closed and semi-closed). Numbers of females housed in closed type were 32927 and 3054 males and semi-closed type were 26744 females and 3670 males. 


\section{El-Faham et al.}

Birds in both housing types were reared in litter floored houses under the same environmental and hygienic conditions, lighting schedule of breeder farm according to the age of chickens was followed. The birds were fed basal laying breeder diet and water was available all the time, vaccination under specific climatic conditions was followed. Collection of data related to broiler breeder flocks, farm details and housing type was used. Measurements recorded were body weight(g), feed consumption per day (g). Mortality rate $(\%)$ was recorded in each flock. Also, egg production percentage were calculated using the equation given by North (1984).

\section{Statistical analysis:}

Data were analyzed using two-way analysis of variance with housing type (closed vs. semi-closed), age and their interaction using the General Linear Model (GLM) procedure of SAS (2002) as following model;

$\mathrm{Y}_{\mathrm{ijk}}=$ Trait measurement

$$
Y_{i j k}=M+A_{i}+H_{j}+(A H)_{i j}+e_{i j k}
$$

$\mathrm{M}=$ Overall mean

$\mathrm{A}_{\mathrm{i}}=$ Age effect

$\mathrm{H}_{\mathrm{j}}=$ Housing type effect $(\mathrm{i}-1,2)$.

$(\mathrm{AH})_{\mathrm{ij}}=$ interaction between housing type and age.

Eijk = Experimental error

When significant differences among means were found, means were separated using Duncan's multiple range tests (Duncan, 1955).

\section{RESULTS AND DISCUSSION}

The effects of housing type and age on productive performance of breeder hens can be shown as follows:

\section{Live body weight:}

The results in (Table 1) indicated that body weight (g) was significantly affected by type of house and age. It is worth to note that body weight for breeder layer hens was significantly heavier under semiclosed housing type compared with those in closed housing type during experimental period (20 wks) and the corresponding values were 3647.31 and $3506.93 \mathrm{~g}$, respectively. Body weight of females increased gradually with advancing of broiler breeder age (3339.8, 3658.9, 3840.3 and $3934 \mathrm{~g})$. Body weight didn't significantly affected by interaction between type of house and age.

Similar results were reported by Sundaramet al. (1979) and Goher et al. (1983) Robinson et al. (1991) and Zaghari et al. (2011) theyreported that body weight and body weight uniformity in males and females were recorded in all flocks from 0 to 65 weeks of age which differences between predicted performances based on breeder management guides and actual broiler breeder performance in the field depend on many environmental factors that influenced commercial broiler breeder performance.

In the same order, Rayan et al. (2015) showed that, body weight of males and females was significantly affected by interaction between housing type and age.

\section{Egg production and egg weight}

Productive performance of breeder broiler chickens as affected by type of house and age are illustrated in Fig. (1) and Table (2). The obtained data showed that three were no significant difference in egg production percentage of breeder under the two housing types (closed and semi-closed). On the other hand, egg production (\%) was significantly affected by breeder age, the highest percentage of production was recorded during 31-35 weeks of age (81.2\%), while the lowest percentage was recorded during 2530 weeks of age $(33.25 \%)$ at the beginning of egg production period.

These results were disagreed with Rayan et al. (2015) and Hameed et al. (2012), they reportedthat egg production percentage was higher under semi-closed housing type as compared to open housing type, but this difference was not statistically significant. However, egg production percentage (\%) was significant affected by breeder broiler chickens age. Furthermore, they stated that environmentally controlled housing system is suggested to breeder farmers as well as broiler farmers in order to get good production results, apart from its higher initial expenditures. It is more profitable to the farmers, easier in management, reduced labor cost, lower risks of diseases, lower mortality, good production percentages and improved quality of egg shells. Egg production per hen housed is comparatively better as compared 
to the open housing system.Also theystated thatCo- relation in controlled housing is higher than the open indicates the controlled housing shown better productive performance than open housing system.

Egg weight was affected by age; it could be observed that the highest value of egg weight $(64.59 \mathrm{~g})$ recorded during production period $41-45 \mathrm{wks}$. of age. The egg weight increased gradually as the breeder age progressed. Similar trend was noticed by Rizzi and Chiericato (2005), who found that the egg weight increased with the hens age.

No significant difference in egg weight of breeder under either the housing types (closed and semiclosed) was realized, also the same trend was observed to interaction effect (Table 2).

These findings agreed with results of some authors investigated that, egg weight increased with layer age in all housing type following the physiological development as reported by Hill and Hall (1980); O'Sullivan et al.(1991); Peebles et al .(2000); Silversides and Scott (2001); Van den Brand et al. (2004) and Rizziand Chiericato (2005).

Nys et al. (2008) suggested thata major impact was the bird aged which effect on the egg weight. The egg weight increased with hen aged varying between 50 and $70 \mathrm{~g}$, however most modern commercial strains are now capable of achieving egg weights of $60 \mathrm{~g}$ by 26 weeks of age and $65.5 \mathrm{~g}$ by 50 weeks, and sustaining this until the end of production.

\section{Feed consumption and mortality rate:}

Data in Table (3) indicated that daily feed consumption per breeder broiler chicken $(\mathrm{g} / \mathrm{d})$ was significantly affected by breeder age. The highest value of consuming feed was recorded during the period of 31-45 weeks of breeder age, when the egg production was at the peak, while the lowest value was recorded during the period of 25-30 weeks of age during the beginning of egg production period. Concerning type of house, no significant difference in consuming feed of breeder under the two housing types (closed and semi-closed) was observed. Also, the interaction between type of house and breeder age was insignificant.

Regardless the housing type, Leesonand Summers (1997) found that egg production was influenced more by metabolisable energy intake than by other nutrients. Neuman et al. (1998) stated that reducing the total daily feed allowance may cause a decline in egg production and performance. Also, they showed that many factors influence broiler breeder performance and reducing the total daily feed allowance may cause a decline in egg production and performance. Therefore, Attia et al. (1995) and Leesonand Summers (1997) stated that low chick production in broiler breeder flocks seems to be due to insufficient feeding and environmental conditions.

The mortality percentage of breeder during egg production period was significantly higher under closed housing type as compared to those housed in semi-closed housing type. There were significant differences for mortality percentage of breeder with age. The highest value of mortality percentage was recorded during period 36-40 weeks of age, while the lower value was recorded during period 25-30 weeks of age. Mortality (\%) was significantly affected by interaction between housing type and breeder age. That means the expression of this trait was differed according to housing type and age (Table 3).

These results in agreement with Daghir (2001); Le-Bihan et al. (2001); Barnett et al. (2001) and Hameed et al. (2012) reported that the mortality percentage of females and males during different rearing periods was markedly higher under open housing type as compared to those housed in semi-closed housing type. Whereas, Le-Bihan et al. (2001); Barnett et al. (2001) and Hameed et al. (2012) indicated that a higher mortality under traditional housing and lower mortality under controlled housing condition. Also, Zaghari et al. (2011) stated thatmortality and culling rate in males and females were recorded in all flocks from 0 to 65 weeks of age which differences between predicted performance based on breeder management guides and actual broiler breeder performance in the field depend on many environmental factors such as heat, light and ventilation.

\section{REFERENCES}

Ashora, M.M.; A. Galal; S.A. El.Safty and O.M. Zatar (2016).Effect of semi-closed and closed housing systems on layers production and economical performance. Egypt. Poult. Sci. 36: 931-948.

Attia, Y.A.; W.H. Burke; K.A. Yamani and L.S. Jensen (1995). Daily energy allotments and performance of broiler breeder females. Poult. Sci. 74:261-270. 


\section{El-Faham et al.}

Barnett, J.L.; P.C. Glatz; A. Almond; P.H. Hemsworth and G.B. Parkinson (2001). A welfare audit for the chicken meat industry: Supporting documentation for the egg industry's national quality assurance programme. Report to Department of Natural Resources and Environment, Melbourne, pp. 5-9.

Bell, D.D. and W.D. Weaver (2001). Commercial chicken meat and egg production, $5^{\text {th }}$ edition. Kluwer, L05 Angeles California, USA.

Daghir, N.J., (2001). Poultry production in hot climates. CAB International, Wallingford, UK.

Duncan, D.M. (1955). Multipl range and multiple F-tests. Biometrics 11:1-42.

Goher, N.E.; F.K.R. Stino; G.A.R. Kamar and N.A. Hanash (1983). The effect of breed and housing system on White Baladi and Fayoumi pullets body weights. Egyptian J. Anim. Prod. 23(1/2): 69-76 (Anim. Breeding Abst. 52(11): 892.

Gomes De Oliveria, R. and L. JaséCamargoslara (2016). Lighting programmes and its implications for broiler chickens. Poult. Sci. J. 72: 735-741.

Hameed, T.; M.A. Bajwa; F. Abbas; A. Sahota; M.M. Tariq; S.H. Khan and F.A. Bokhari (2012). Effect of housing system on production performances of different broiler breeder strains. Pakistan J. Zool., 44: 1683-1687.

Hassanien, M.S. (2015). Studies on some factors affecting on productive performance of meat type parent stocks. Ph.D. Thesis, Ain Shams University.

Hill A.T. and W. Hall (1980). Effects of various combinations of oil spraying, Washing, sanitizing, storage time, strain, and age of layer upon albumen quality Changes in storage and minimum sample sizes required for their measurement. Poultry Science. 59: 2237-2242.

Kosba, M.A.; H.S. Zeweil; S.M. Zahran; M.A. Elshafe and T.M. Mohamed (2015). A comparative study among three parental broiler stocks under Egyptian conditions. Egypt. Poult. Sci., 35: 979-990.

Le-Bihan, D., C. Berri;E. Baeza;N. Millet and C. Beaumont (2001).Estimation of the genetic parameters of meat characteristics and of their genetic correlations with growth and body composition in an experimental broiler line. Poult. Sci., 80:839-843.

Leeson, S. andJ.D. Summers (1997).Commercial Poultry Nutrition. $2^{\text {nd }}$ Location on Feed Intake and Performance of Scavenging Chickens in Long-term caging and moult of single comb White Leghorn Hens on Manual.4th Ed. New York: Van Nostrand Reinhold.

Neuman, S.L.; R.H. Harms and G.B. Russell (1998). An innovative change in energy restriction for broiler breeder hens. J. Appl. Poult. Res. 7:328-335.

North, M.O. (1984). Breeder Management. In commercial chicken production Manual. The AVI. Publishing Company. Inc. Westport, Connecticut. 240-243, 298-321 pp.

Nys Y.; T.Burlotand I.C. Dunn (2008). Internal quality of eggs: any better, any Worse? XXIII World's Poultry Congress, Brisbane, Australia, June 30-July 4, World's Poultry Science Association (Australian branch). 113. (CD-ROM) (papers Ilwpc08Final00034).

O’sullivan N.P.;E.A. Dunnington andP.B. Siegel (1991).Relationships of Nigerian indigenous chickens from three agro-ecological zones. Livestock research for development 13:2.

Peebles E.D.;C.D. Zumwalt;S.M. Doyle;P.D. Gerard;M.A. Latour;C.R. Boyle andT.W. Smith (2000). Effects of breeder age and dietary fat Source and level on broiler hatching egg characteristics. Poultr Science. 79: 698-704.

Rayan, G.N.; S.A. El-Safty and M.S. Hassanien (2015). Effect of age, housing type and their interaction on broiler breeder performance during growth and egg production periods. Egypt. Poult. Sci. 35: 261 276.

Rizzi C. andG.M. Chiericato (2005).Organic farming production. Effect of age on the productive yield and egg quality of hens of two commercial hybrid lines and Two local breeds. Italian Journal of Animal Science. 4:160-162.

Robinson, F.E.; N.A. Robinson and T.A. Scott (1991). Reproductive performance growth rate and body composition of full feed versus feed restricted broiler hens. Can. J. Anim. Sci. 71:549-556.

SAS institute (2002). SAS/STAT Users Guide statistics Ver.9.1; SAS institute Inc. Cary, NC.

Silversides F.G. and T.A. Scott (2001). Effect of storage and layer age on Quality of eggs from two lines of hens. Poultry Science. 80:1240-1245.

Sundaram, T.S.T.; P.Kothandaramn and K.Kumaraswamy (1979). Effect of strain and housing on White Leghorn pullet performance. Indian J. Poult. Sci. 14(1): 1-8 (Anim, Breeding Abst. 49(7): 501, 1981).

Van Den Brand H., Parmentier H.K. and B. Kemp (2004). Effects of veterinary Science, 50:52-58. 
Zaghari, M.; F. Fazlali; A. Gerami; N. Eila and S. Moradi (2011). Effects of environmental factors on the performance of broiler breeder hens. J. Appl. Poult. Res. 20: 383-389.

الأداء الإنتاجى لأمهات التسمين "هبرد كلاسيك" المرباة تحت نظم إسكان مختلفة

أحمد إبراهيم الفحام، سيد عبد الرحمن إبراهيم، صلاح الدين عبد الرحمن الصفتى، محمد سامى حسنين، نعمة الله جمال الدين وجمال ناجى ريان

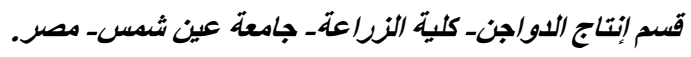

لبهاف من التجربة النعرف على ثأثير نو عين من المزارع (مغلقة ونصف مغلقة) وعمر أمهات التسمين "هبرد كلاسيك" والتداخل

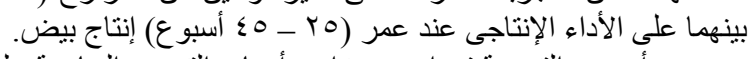

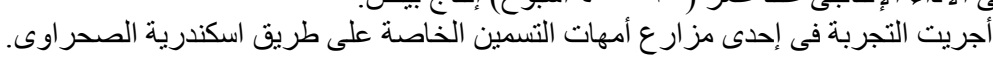

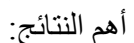

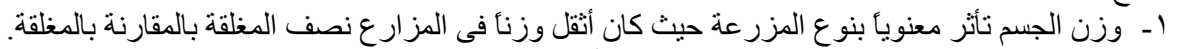

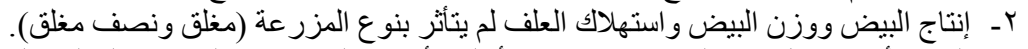

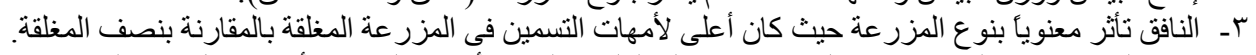

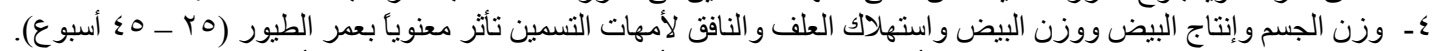

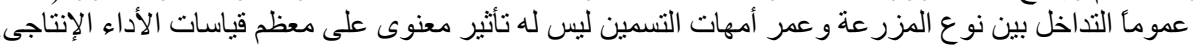

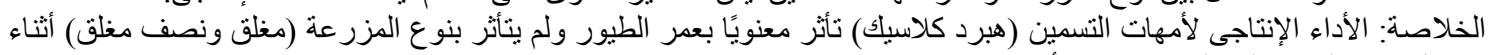
مر احل إنتاج البيض المختلفة (10 ـ0 ؛ أسبوع). 
Table (1): Effect of type of house at different ages on body weight (g) of Hubbard classic broiler breeders females during egg production period

\begin{tabular}{|c|c|c|c|c|c|c|c|}
\hline \multirow{2}{*}{ Trait } & \multirow{2}{*}{$\begin{array}{l}\text { Age, of wk } \\
\text { (A) }\end{array}$} & \multicolumn{2}{|c|}{ Type of house $(\mathrm{T})$} & \multirow{2}{*}{ Overall } & \multicolumn{3}{|c|}{ Probability } \\
\hline & & Closed & Semi-closed & & $\mathrm{T}$ & A & $\mathrm{T} * \mathrm{~A}$ \\
\hline \multirow[t]{6}{*}{ Body weight, $g$} & & & & & 0.05 & 0.0001 & NS \\
\hline & $25-30$ & $\begin{array}{c}3241.00 \\
\pm 88.72\end{array}$ & $\begin{array}{c}3438.67 \\
\pm 91.59\end{array}$ & $3339.80^{c}$ & & & \\
\hline & $31-35$ & $\begin{array}{c}3637.40 \\
\pm 30.95\end{array}$ & $\begin{array}{c}3694.67 \\
\pm 10.73\end{array}$ & $3666.04^{b}$ & & & \\
\hline & $36-40$ & $\begin{array}{c}3779.00 \\
\pm 27.00\end{array}$ & $\begin{array}{c}3901.50 \\
\pm 93.50\end{array}$ & $3840.30^{\mathrm{ab}}$ & & & \\
\hline & $41-45$ & $\begin{array}{c}3906.00 \\
\pm 25.00\end{array}$ & $\begin{array}{c}3948.00 \\
\pm 27.00\end{array}$ & $3927.00^{\mathrm{a}}$ & & & \\
\hline & Overall & $3506.93^{b}$ & $3647.31^{\mathrm{a}}$ & & & & \\
\hline
\end{tabular}

Table (2): Effect of type of house at different ages on egg weight (g) of Hubbard classic broiler breeders females during egg production

\begin{tabular}{|c|c|c|c|c|c|c|c|}
\hline \multirow{2}{*}{ Trait } & \multirow{2}{*}{$\begin{array}{l}\text { Age, of wk } \\
\text { (A) }\end{array}$} & \multicolumn{2}{|c|}{ Type of house (T) } & \multirow{2}{*}{ Overall } & \multicolumn{3}{|c|}{ Probability } \\
\hline & & Closed & Semi-closed & & $\mathrm{T}$ & A & $\mathrm{T} * \mathrm{~A}$ \\
\hline \multirow[t]{10}{*}{ Egg weight, g } & & & & & NS & 0.0001 & $\mathrm{NS}$ \\
\hline & $25-30$ & 54.28 & 55.50 & $55.01^{c}$ & & & \\
\hline & & \pm 1.44 & \pm 0.76 & & & & \\
\hline & $31-35$ & 60.58 & 60.92 & $60.75^{b}$ & & & \\
\hline & & \pm 0.46 & \pm 0.66 & & & & \\
\hline & $36-40$ & 63.10 & 64.52 & $63.81^{a}$ & & & \\
\hline & & \pm 0.30 & \pm 1.07 & & & & \\
\hline & $41-45$ & 63.88 & 65.30 & $64.59^{a}$ & & & \\
\hline & & \pm 0.20 & \pm 0.17 & & & & \\
\hline & Overall & 60.78 & 61.27 & & & & \\
\hline
\end{tabular}

${ }_{a, b \text { and } c}$ Means within the same main effects with different letters are significantly differed,

$N S=$ Non-significant 
Table (3): Effect of type of house at different ages on consuming feed and mortality percentage of Hubbard classic broiler breeders females during egg production period

\begin{tabular}{|c|c|c|c|c|c|c|c|}
\hline \multirow{2}{*}{ Trait } & \multirow{2}{*}{$\begin{array}{l}\text { Age, of wk } \\
\text { (A) }\end{array}$} & \multicolumn{2}{|c|}{ Type of house (T) } & \multirow{2}{*}{ Overall } & \multicolumn{3}{|c|}{ Probability } \\
\hline & & Closed & Semi-closed & & $\mathrm{T}$ & A & $\mathrm{T} * \mathrm{~A}$ \\
\hline \multirow[t]{6}{*}{$\begin{array}{l}\text { Feed consumption, } \\
\text { g/day }\end{array}$} & & & & & NS & 0.0001 & NS \\
\hline & $25-30$ & $\begin{array}{c}146.70 \\
\pm 9.40\end{array}$ & $\begin{array}{c}148.83 \\
\pm 7.41\end{array}$ & $147.45^{\mathrm{b}}$ & & .0001 & 100 \\
\hline & $31-35$ & $\begin{array}{c}175.00 \\
\pm 0.36\end{array}$ & $\begin{array}{l}172.60 \\
\pm 1.50\end{array}$ & $173.80^{\mathrm{a}}$ & & & \\
\hline & $36-40$ & $\begin{array}{c}173.60 \\
\pm 0.40\end{array}$ & $\begin{array}{c}167.80 \\
\pm 0.20\end{array}$ & $170.70^{\mathrm{a}}$ & & & \\
\hline & $41-45$ & 173.00 & 167.00 & $170.00^{\mathrm{a}}$ & & & \\
\hline & Overall & $\begin{array}{c} \pm 0.01 \\
165.92\end{array}$ & $\begin{array}{l} \pm 0.01 \\
163.33\end{array}$ & & & & \\
\hline \multirow{9}{*}{$\begin{array}{l}\text { Mortality } \\
\text { percentage }(\%)\end{array}$} & & & & & 0.0004 & 0.05 & 0.02 \\
\hline & $25-30$ & 0.49 & 0.13 & $0.31^{\mathrm{a}}$ & & & \\
\hline & & \pm 0.01 & \pm 0.01 & & & & \\
\hline & $31-35$ & $\begin{array}{c}0.31 \\
+0.03\end{array}$ & $\begin{array}{c}0.18 \\
+0.03\end{array}$ & $0.24^{\mathrm{ab}}$ & & & \\
\hline & $36-40$ & 0.35 & 0.27 & $0.31^{\mathrm{a}}$ & & & \\
\hline & & \pm 0.10 & \pm 0.01 & & & & \\
\hline & $41-45$ & 0.29 & 0.30 & $0.29^{\mathrm{a}}$ & & & \\
\hline & & \pm 0.02 & \pm 0.01 & & & & \\
\hline & Overall & $0.33^{\mathrm{a}}$ & $0.22^{b}$ & & & & \\
\hline
\end{tabular}

${ }^{a \text { and } b}$ Means within the same main effects with different letters are significantly differed, $N S=$ Non-significant

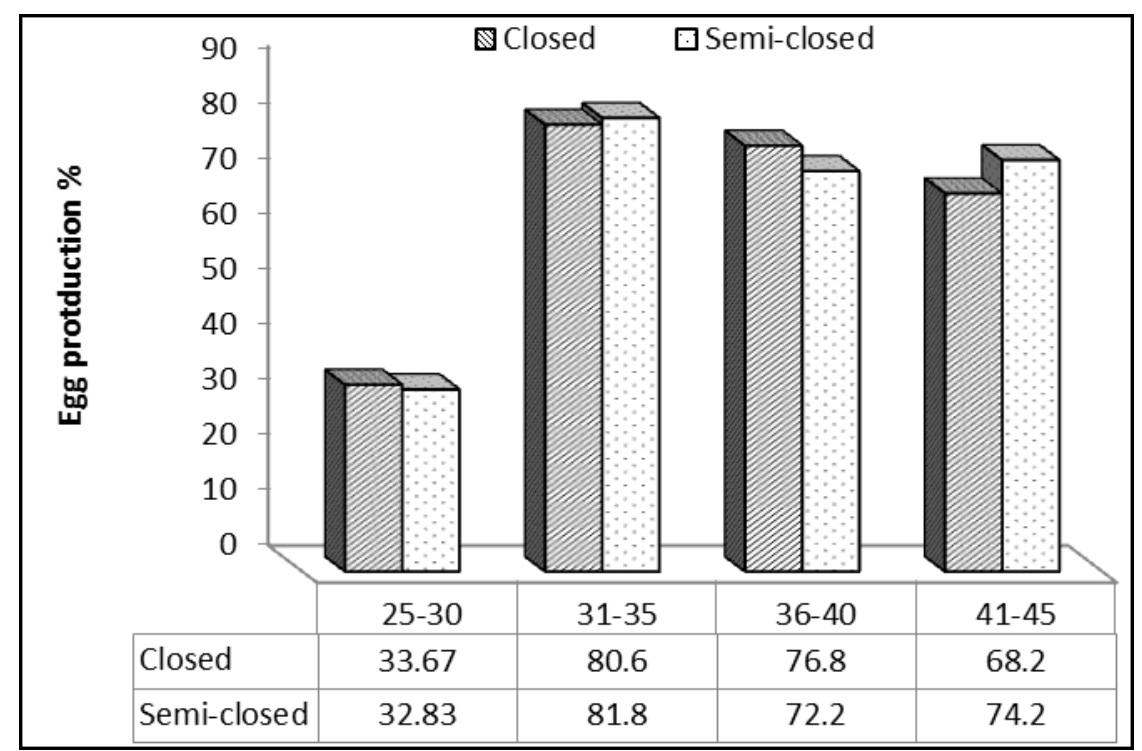

Fig. (1): Effect of type of house on egg production(\%) of Hubbard classic broiler breeders females. 
El-Faham et al. 